\title{
THE FLINT IMPLEMENTS OF SUB-CRAG MAN.
}

\author{
(Read at Norwich December Iath, 19I0; re-written from a paper \\ read at Ipswich on March 23rd, 1910.)
}

\section{BY J. REID MOIR.}

On the 3rd of October, 1909, I found on a stone heap in Messrs. Bolton and Laughlin's brickfield near Ipswich a large flint implement fashioned from a cylindrical nodule and flaked to a cutting edge at one end. This implement, which is obviously very massive, weight $8 \frac{3}{4} \mathrm{lbs}$., is deeply patinated on its worked surfaces a yellowish-brown colour, and has a very hard ferruginous deposit attached to portions of its crust.

Following on this discovery I commenced searching for others, and eventually found them lying on the London Clay under a seam of decalcified crag. and associated with many bones and phosphatic nodules such as are met with at other ordinary bases of the Red Crag. This decalcified crag occurs in two basinshaped hollows, one 56 yards wide and the other 45 yards, in the London Clay. The general arrangement of the beds (Plate I.) in the hollows is as follows:-

1. Top sand and gravel, in places up to 9 feet in thickness.

2. Middle Glacial Sands, with sarsen stones, maximum thickness 12 feet to 15 feet.

3. Decalcified crag, with casts of shells up to 3 feet. This is very hard in the eastern hollow, and rests upon an uneven floor of London Clay, containing pockets filled with pebbles, and boulders of flint and micaceous sandstone.

In the extreme Western end of the Eastern hollow a patch of chalky Boulder Clay occurs. As the beds in the hollows are evidently part of the same series (as shown in a pit a few hundred yards eastward, where they are covered by undisturbed 1 Boulder Clay), I conclude that at one time the contents of the two hollows were also capped by it. This clay has now mostly been denuded, except the small patch in the eastern hollow, and a few others which occur towards the surface of the London Clay between the hollows. The reasons why I conclude that the sands and gravel in the two hollows are the same as in the pit further eastward are as follows:-

1. They are all of the recognised Middle Glacial series, which occurs over such a wide area of Eastern Suftolk.

2. The gravels all contain exactly similar edge-chipped flints and the same fossils.

3. The sands all have sarsen stones.

I believe that the Boulder Clay at the top pit has escaped complete denudation because it is at a higher level, where it would not be subjected to the wash-out of the Gipping Valley. This wash-out no doubt carried away the Boulder Clay above the two hollows which are situated at a lower level. The London Clay in the brickfield in which the two hollows occur shows 
evident signs of having been subjected to great pressure, as the eastern sides of the hollows are buttressed up against the decalcified crag and Middle Glacial Sands in a most remarkable manner. But as the latter curl upwards with the London Clay it is evident they were deposited before the contortion took place. This contortion was very probably associated with the deposition of the top Boulder Clay.

My opinion is that the decalcified crag in the bottom of the two hollows, where it would naturally be protected, is in situ, and represents the eroded base-bed of the Red Crag. This is evidently the opinion of Mr. Whitaker, F.R.S. (late of His Majesty's Geological Survey), who visited the spot with me, for in a letter dealing with this particular section he says, "I don't think there is anything approaching to rashness in taking this thin, and perhaps impersistent bed, as far as that section is concerned, as the base-bed of the Red Crag left adherent to the London Clay, the rest of the formation having been eroded. That seems to me the most rational explanation of the section." In further support of my contention that this stratum is in situ, I would say that a number of my implements are quite unabraded, so that they could not have been rolled by water action to their position. Also the flints themselves are exactly similar in every way to those found in the base-beds of undisturbed crag all over the district, and which are found only in association with crag. Their characteristics are that they have peculiar iron stainings running in lines over their crusts, and when broken show an unchanged black interior. This differentiates them from those from the Middle Glacial sands and gravels, most of which are changed flints.

Besides this, the flints from the two hollows have a very hard ferruginous deposit over their worked surfaces, which when chipped off and subjected to H.C.L. gives off a definite effervescence, showing the presence of calcium carbonate. This again testifies to their sub-crag age, as in Middle Glacial gravels, etc., calcium carbonate is very rare, it having been dissolved out by water. As also the hardness of this base bed (which contains nothing foreign to the ordinary base bed of the shelly crag) precludes any chance of the flints having dropped through to the London Clay below, it is evident that this bed is undisturbed and my flints pre-date the particular crag under which they now lie.

I have now also found exactly similar flint implements lying on the London Clay at Greenwich Farm, and the Back Hamlet, Ipswich, and at Thorington Hall, Wherstead. At Greenwich Farm under about 30 feet of decalcified crag; at the Back Hamlet under 15 feet of very shelly Red Crag; and at Thorington Hall, Wherstead, under 13 feet of the same deposit. All these three beds have a superficial deposit of glacial drift composed of gravel or chalky Boulder Clay.

Regarding the crag at the Back Hamlet and Thorington Hall, there ean be no doubt that it is quite undisturbed, as the 
flints at the base have barnacles attached to them and the sections are full of quite unbroken shells.

The Thorington Hall crag pit was visited with me by Mr. W. Whitaker, F.R.S., and Professor Watts, F.R.S., and pronounced by them to be in situ.

At Greenwich Farm the crag is shell-less, and therefore there is a chance that it may not be undisturbed; but the great thickness of the deposit and the fact of the usual sub-crag flints being found beneath it points, I think, to it being in situ.**

I have found my implements also in crag pits at Foxhall, Buckanay, and Bawdsey, the specimens being picked up where they had been evidently thrown out when the pits were worked for coprolites.

Since I have only found these implements actually in situ at Bolton and Laughlin's brickfield, the Back Hamlet, Greenwich Farm, and. Thorington Hall, all of which pits are within the Newbournian zone of the Red Crag, I can only at present claim that my finds are of pre-Newbournian crag age. But further investigations are in progress with a view to opening up other sections where the actual Basement Bed of all the crags occurs, and if I find my implements there in situ, then I shall have proved that they are undoubtedly of actual pre-crag age.

Man's work has been identified on the flaked flints by Sir E. Ray Lankester, F.R.S., Dr. Blackmore and Mr. Westlake, F.G.S., of Salisbury, Dr. W. Allen Sturge, M. Rutot, Mr. Benjamin Harrison, Dr. F. Corner, F.G.S., Mr. A. S. Kennard, F.G.S., Mr. F. J. Bennett, F.G.S., Mr. E. R. H. Hancox, Mr. Percy Martin, Miss Nina F. Layard, F.L.S., Lt.-Col. Underwood, and many others.

The acceptance of some of these flaked flints one would imagine could not be refused, as their workmanship and intention is identical with the universally-accepted palæoliths; but there are some, amongst whom I may mention Professor Boyd Dawkins and Mr. Hazzeldine Warren, who after seeing my specimens when on exhibition at Burlington House, London, told me that they were undoubtedly the result of natural forces and nothing else.

Of course, Professor Boyd Dawkins' attitude is understandable, as he has publicly stated in his Huxley Memorial Lecture, given just lately, that in his opinion man did not arrive on the scene till the Pleistocene Period, and therefore flaked flints from any older strata cannot of necessity be man's work. His argument is that as the other mammalia have altered so much since Pliocene times, man must have done so too, and therefore, I presume, he was so much akin to the simians as to be quite unable to chip flints, or, to put it shortly, was not possessed of even a rudimentary intelligence.

* Since this paper was read, implements have been found under a section of undisturbed shelly crag at Greenwich Farm. 
Personally I do not agree with this opinion, as I know of no certain evidence upon which it is based. We have no bones which tell us what the Pliocene representative of the genus Homo was like, and how do we know that man undergoes such rapid anatomical chang as the other mammalia? The evidence on this last point is, I think, quite in opposition to Professor Boyd Dawkins' opinion, as it is well known that the Palæolithic skulls from Corrèze, the Neanderthal Cave, Spy, and Gibraltar, though belonging to men who were contemporary with animals which widely differ from their present-day representatives, have an actually larger cubic capacity than some of the modern European skulls. Also the complete skeletons of Palæolithic Age which have been found do not differ in any. marked degree from modern races, and as this is so I do not think it at all unreasonable to conclude that man existed in Pliocene times, and my implements prove to me that, though perhaps not highly intelligent, he had anyway no small knowledge of flint-chipping.

Mr. Hazzeldine Warren, in examining my specimens, said that every one of them had been produced by natural forces, and though I was unable to ascertain from him exactly what forces: he considered had operated on them, I presume these would take the form of blows or pressure.

Now the most likely place in Nature where flints are subjected to sharp and continuous blows is in a fast-running river, or on a sea-beach (where, however, angular stones are soon converted into pebbles), and to simulate the action of these two agencies I put about ten broken flints into a sack and shook them violently about (so that they were all continually striking against each other) for some considerable time.

The result was that when taken out all the flints showed where the various blows had impinged on their surfaces, and while some very few and quite random edge chips had been taken off, it was at once obvious that they bore not the slightest resemblance to man's work in any shape or form.

(Mr. Warren showed me a well-worked Neolithic flake which he had picked up on a beach, and had labelled "wave action;" but why everything found on a beach should be the result of wave action I do not know.)

The only way to convince me that Nature can produce the flints which I am showing is by the supporters of this theory producing by natural agencies a series at all comparable with my beak-shaped and chopper-like forms, rubbers, pounders, \&c. It is useless their showing me flaked flints picked up on a sea-beach or in a gravel, and saying, "These have been made by Nature." This is merely to beg the question, for we require something more than their "ipse dixit" that such forms are natural and not of human workmanship. I repeat that they must actually make them by agencies corresponding with natural forces; otherwise their statement that Nature made them is. absolutely valueless. 
Now they have not produced duplicates of my specimens by such agencies. Miss Nina Layard, on the other hand, has produced them by ordinary flaking with a hammer. The evidence thus far is therefore in favour of my flints having been artificially flaked.

Regarding pressure, I will at once admit that under certain circumstances it is possible to produce fine edge work on a flint, and $I$ have done it by placing one flint on another and turning on my heel on them, also by putting them in a press.

My experiments have shown me that it requires quite a heavy pressure to produce even edge work, and I have been unable to produce the large flakes such as my implements show, for when the flints are subjected to great pressure shattering takes place. Though it is possible to produce edge-work by natural means, it is as well to remember that the physical condition of most gravels would not allow of flints being subjected to pressure such as would flake their edges, and in the case of the now famous pieces found by M. Breuil, the chalk which was lying just below them would no doubt offer the necessary hard surface to hold one flint up against another when the pressure was operating.

But I am not convinced that M. Breuil's specimens are in the first place drawn correctly, drawings being often unintentionally misleading, or that they zere produced by pressure, as I find fragile unbroken shells under 50 feet of glacial drift and crag, and surely if pressure will flake flints in a gravel, it ought to break these shells.

Now a number of my implements show extensive surface work which cannot possibly have been produced by river or sea action or by pressure, and as thermal fissure cannot seriously be contemplated, it is evident that these flints were flaked by one agency and one agency only, namely-man.

It has been stated that the Kentian Eoliths have been flaked by pressure and my specimens by percussion, which implies that Nature in Eolithic times had a difterent method and intention with flints than later on when dealing with the sub-crag pieces.

A large number of the Kentian Eoliths show signs of waterrolling, and the sub-crag flints of pressure, and if water-rolling and consequent percussion will cause flaking like that showing on my flints, how is it it does not occur on the Eoliths? Also how is it that my flints which show distinct signs of having been subjected to pressure (by the striations which appear on their surfaces) have not been flaked by that process which is said to have flaked the Eoliths? These question:s require answering, but I have grave doubts whether they ever will be satisfactorily, as the "Natural Forces" men cannot have it both ways.

Mr. Hazzeldine Warren stated that the flaking on my specimens did not "show control"-and hy this I take it he meant that it always takes the line of least resistance. This opinion must have been the result of a very cursory glance at my series, 
as many of them show that their makers very often had to chip against the grain of the flint, and that repeated blows were necessary to detach the required flake. Some of my specimens show the bulb of percussion with the "striking surface" welldeveloped, which is, I understand, an almost certain guarantee of man's work. These sub-crag flints exhibit on their crusts and surfaces very marked striations, which are very remarkable and bring up some very important considerations.

In the first place the striations are in most cases very deep, and have caused an actual shattering of the surface of the flint, and when the extreme hardness of flint is remembered it is obvious that only something as hard or harder acting with great pressure can have been responsible for them. The only agent which I can think of which is capable of producing such striations is ice, with flints or quartzites in its grasp, and as these scratched flints are found beneath undisturbed crag, surrounded in many cases by unbroken fragile shells, and with barnacles of the crag sea attached to them, it is evident that the striation occurred prior to the deposition of the crag. We may, therefore, have to recognise a glaciation in early Pliocene or pre-Pliocene times, which was separated by an immense period from what are generally known as the Great Ice Ages.

I have classed my implements as pre-palæoliths-that is to say, they represent a stage of culture mid-way between the Eoliths proper and the river drift palæoliths-being similar in some respects to both; the edge chipping which gives them an Eolithic appearance is, however, supplemented by definite surface flaking, which allies them to the subsequent palæoliths. I therefore recognise them as transitional forms, and have consequently called them pre-palæoliths. These transitional forms are generally discovered in high-level gravels, and if they are of the same age as mine, then it means either that the crag under which my specimens lie is not so old as we imagine, or that the high-level gravels are much older.

It may be, perhaps, unwise to draw such inferences, as we have to consider the possibility of retrogession. This certainly played a part in the later periods of the stone ages, and it may well have operated in these earlier periods. Thus though two series of flints from different sites may appear to be of the same type, they may, nevertheless, be of totally different degrees of antiquity, and may be separated by periods of lower culture. The majority of $\mathrm{my}$ implements are stained a deep brown colour (the true sub-crag patina being, however, porcellanous), but I have some which are quite unstained and unpatinated. These latter are all unabraded and unscratched, and certainly do not appear to be so old as the others, but it is possible they may have got buried in the London clay soon after they were made, and thus have remained untouched by the agents which have affected the others. The specimens can be divided up into several well-defined types, viz., Rubbers, Pounders, Beak-shaped 
Implements, Choppers, Implements with a cutting edge at one end, Scrapers, Struck and Trimmed Flakes. The Rubbers of which I have got many examples bave been made by splitting a flint pebble and using the resulting flat surface for the purpose required. They generally show the bulb of percussion, formed when the pebble was split, and in many instances the surface was flaked off to make it flat. Edge work, moreover, is of very frequent occurrence, and in every case where the shape of the pebble did not allow of a comfortable handgrip. it has been flaked to the required form. The description I have given of the Rubbers can be applied to the Pounders, which are, however, always fashioned from a differently-shaped flint nodule, and I would suggest were used for crushing various substances for food. The Beak-shaped specimens are very interesting, and are generally made from a narrow flint pebble which has been deftly chipped on both sides of one end and squared off underneath to produce the "beak." The Choppers are a rarer form, but have also been formed from flint nodules, generally large, boldly shaped to a definite cutting-edge, and provided with an excellent handgrip. The Implements which are chipped to a cutting-edge are usually massive too, and fashioned from cylindrical nodules of flint which have been flaked up to a cutting-edge from both sides of one end; in many cases they appear to have been used in both hands. The Scrapers are generally made out of split Tertiary pebbles, but I have some which have been fashioned from struck flakes; both bollow and other forms occur.

The Struck and Trimmed Flakes are not numerous, but those I have got are quite definite and some very large. Other erratic forms occur, and one sample deserves special notice, as it has been fashioned from a flake which shows a large bulb of percussion, and has then been worked with long flakings to an almost exact representation of a later palæolith; in fact, it is the most advanced type I have yet got from below the crag.

The long parallel flaking which occurs on so many of my implements appears to me to differentiate them from any other type I have seen, and it may be proved that they form a class of their own. My opinion is that, judging from the unabraded condition of many of my flints, the London Clay on which they lie was at one time a land surface, and that the patina which is seen on them was formed while they were lying exposed on that land surface. This opinion is supported by the evidence of the Neoliths which are found upon the surface of the fields, and some of which by exposure have acquired an exactly similar patina to my sub-crag specimens. Also I have irrefutable evidence that before they were covered by the waters of the crag sea they were subjected to some agency which scratched them, and the only agent I can conceive of as being capable of producing such scratches as we see upon them is ice. 
In conclusion I would say that, by finding these definitely well-worked flints (which are far in advance of the Kentian Eoliths) in their true stratigraphical position below crag, I have proved that since their makers lived the following beds have been laid down, viz., the Newbournian Crag, the Butleyan Crag, the Norwich Crag, the Chillesford Crag and Sand, the Weybournian Crag, the Cromer Beds, and the Glacial Series.

This gives Man an antiquity in these islands never before recognised, and if further investigations prove the occurrence of these pre-palæoliths at the basement bed of all the crags, then this antiquity is infinitely greater still, and even then we have not got back to the dawn of human intention, as the Eoliths still remain to be accounted for.

Mr. Lewis Abbott will shortly publish a paper upon the physics of these flints, and hopes to be able to show that these effects could not have been obtained by any natural process with which we are acquainted, or any combination of natural forces, but that they evince the same intelligence displayed in the manufacture of similar tools from otber horizons, one of the groups of tools lasting down to historic times. A series of this group was exhibited in the Anthropological Sectior at the Anglo-Japanese Exhibition last year.

\section{REPORT OF THE SPECIAL COMMITTEE.}

After the discussion of Mr. Moir's paper it was decided to appoint a Special Committee to enquire into and report upon the question whether the flints exhibited by him had been chipped by natural or by human agency. The following members of the Society were accordingly invited to form the special Committee :-Lieut.-Col. Underwood (President of the Society), Dr. W. Allen Sturge (Vice-President), Mr. W. G. Clarke (Secretary), Miss Nina Layard, F.L.S., Dr. Corner, F.G.S.

The Special Committee met by invitation of Dr. Sturge at Icklingham Hall from December 17th to 19th, 1910; Mr. Moir's paper and specimens having been previously sent there.

The flints submitted to us by Mr. Moir consisted of 35 from Bolton and Laughlin's pit at Ipswich, three from Foxhall Crag pit, two from Thorington Hall Crag pit, four from Back Hamlet Crag pit, and one from Alderton. There were in addition 20 flints from Bolton and Laughlin's pit which were in Dr. Sturge's possession previously - samples given to him by Mr. Moir. categories.

The flints could be placed into three rather sharply-defined 